Original Research Paper

\title{
Application of Water Hyacinth Liquid Bio-Organic Fertilizer Using Trichoderma Sp Bio-activator on Growth and Production of Green Mustard Plants (Brassica rapa var. Parachinensis)
}

\author{
Febiayu Aloatuan ${ }^{*}$, Centhya Victorin Maitimu \\ ${ }^{1}$ Biology Education Study Program, STKIP Gotong Royong Masohi, Central Maluku, Indonesia. \\ ${ }^{2}$ Faculty of Animal Husbandry, University of Victory Sorong, West Papua, Indonesia
}

\author{
Article History \\ Received : September $11^{\text {th }}, 2020$ \\ Revised : September $23^{\text {th }}, 2020$ \\ Accepted : October $16^{\text {th }}, 2020$ \\ Published : November $01^{\text {th }}, 2020$ \\ *Corresponding Author: \\ Febiayu Aloatuan, \\ Biology Education Study \\ Program, STKIP Gotong Royong \\ Masohi, Central Maluku, \\ Indonesia. \\ Email: aloatuanfeby@gmail.com
}

\begin{abstract}
Mustard greens (Brassica rapa var. Parachinensis) are known vegetables among consumers and have high economic value. Besides being used as a vegetable, mustard greens are also used for the treatment of various diseases so that they are included in the vegetable group which has an important role in meeting the needs of food, nutrition and medicine for the community. To increase the growth and production of green mustard plants, it is necessary to apply liquid bio-organic fertilizers that are sourced from organic materials with good nutrients needed by plants, one of which is water hyacinth weed. To improve the quality of water hyacinth liquid bio-organic fertilizer, it can be applied with the bioactivator Trichoderma $s p$ which functions to produce liquid bio-organic fertilizer with high nutrients for plant growth and production. The purpose of this study was to determine the growth of mustard greens including plant height, number of leaves and leaf width and to test the production of mustard greens including caratenoids and vitamin $\mathrm{C}$ content. This study used a completely randomized design (CRD) with a single factor, namely fertilizer. Liquid organic (POC) water hyacinth fermented using Trichoderma sp. which consists of 5 levels of fertilization doses, namely A $(0 \mathrm{ml} / \mathrm{L}), \mathrm{B}(8 \mathrm{ml} / \mathrm{L}), \mathrm{C}(16 \mathrm{ml} / \mathrm{L}), \mathrm{D}(24 \mathrm{ml} / \mathrm{L})$ and $\mathrm{E}(32 \mathrm{ml} / \mathrm{L})$ with 5 repetitions. Based on the results of analysis of variance, it showed that the dosage treatment of water hyacinth bio-organic fertilizer with the bio-activator Trichoderma sp had a significant effect on $\mathrm{p}<0.05$ on plant height, leaf width and the number of green mustard leaves at 4 weeks of age 21 day after planting. with the results of the chemical content test which showed that treatment $\mathrm{E}(32 \mathrm{ml} / \mathrm{L})$ contained Karetenoid $(0,2596 \mathrm{mg} / 100 \mathrm{~g}$ of material $)$ and vitamin $\mathrm{C}(0.2784 \mathrm{mg} / 100 \mathrm{~g}$ of material). The best dose based on the results of the study was treatment $\mathrm{E}(32 \mathrm{ml} / \mathrm{L})$ which had a higher average plant height, leaf width and number of leaves compared to other treatments and had high vitamin $\mathrm{A}$ and vitamin $\mathrm{C}$ content. To increase the growth and production of mustard greens and other horticultural cultivation processes, it is advisable to use liquid bio-organic fertilizer for water hyacinth with the bio-activator Thricoderma sp as an alternative to natural, environmentally friendly liquid organic fertilizer.
\end{abstract}

Keywords: Green mustard; liquid bio-organic water hyacinth; bio-activator of Trichoderma sp.

\section{Introduction}

Green mustard plant (Brassica rapavar. Parachinensis) is a type of vegetable that is well known to consumers and has high economic value (Erawan et al., 2013). Green mustard apart from being a vegetable, can also be used for the treatment of various diseases so that it is included in the vegetable group which has an important role in meeting the needs of food, nutrition and medicine for the community (Istrofah et al, 2017). The demand for mustard plants always increases along with the 
increasing awareness of nutritional needs. Therefore, to meet consumer needs, it is necessary to increase the production of green mustard. However, in increasing crop productivity farmers tend to use inorganic fertilizers which can continuously reduce crop production and the soil will experience degradation (damage). This impact has now become a global concern, so it is necessary to apply sustainable organic agriculture by utilizing organic materials such as water hyacinth plants (Apzani et al, 2017).

Water hyacinth (Eichonia crassipes) is an aquatic plant that floats and has a high growth speed so that this plant is considered a weed that can damage the aquatic environment (Juliani et al., 2017). Water hyacinth has been recognized as the most dangerous weed in the world because of its negative effects on plants and waters (Osoro et al, 2014). One of the prospective efforts to tackle water hyacinth weeds is to use water hyacinth plants as organic fertilizer because there are nutrient elements needed by plants and can be used as organic fertilizers, including $\mathrm{N}$ nutrient elements of $1,86 \%, \mathrm{P}$ of $1,2 \%, \mathrm{~K}$ of $0,7 \%$, $\mathrm{C} / \mathrm{N}$ ratio of $6,18 \%$, organic matter of $25,16 \%$ and Corganic of 19,61\% (Wulandari et al., 2016).

Organic fertilizers are fertilizers made from organic materials such as vegetable scraps, livestock manure and so on and also come from living things that have died (Hadisuwito, 2012). Liquid organic fertilizer is a fertilizer whose chemical content can provide nutrients that are in accordance with the needs of plants on the soil (Taufika, 2012). The process to accelerate composting of liquid organic fertilizers can be accelerated by the addition of microorganisms as decomposers (Martanah, 2013). The type of microorganism determines the success of the composting process, such as the fungus Trichoderma sp. Trichoderma sp is also known as a biological activator that is active in changing organic matter into inorganic compounds (Lestari et al, 2017).

Based on the background, this study aims to measure the parameters of plant height, number of leaves and leaf width of mustard greens and to test the, caratenoids and vitamin $\mathrm{C}$ content of green mustard vegetables from the application of water hyacinth liquid bio-organic fertilizer using the bio-

activator Trichoderma sp. In addition, this research also aims to minimize the use of inorganic fertilizers and prevent the growth of water hyacinth weeds and determine the best water hyacinth dosage as liquid organic fertilizer to support the productivity of green mustard plants, so that it can be used as material for scientific information to the public.

\section{Materials and Methods}

\section{Time and Place of Research}

This research was conducted in a mini green house and the Basic Biology Laboratory of STKIP Gotong Royong Masohi and the Basic Chemistry Laboratory of the Pattimura University in Ambon. This research took place from July to August 2020.

\section{Materials and Tools}

The materials used in this study were green mustard seeds (Brassica rapavar. Parachinensis), water hyacinth (Eichhornia crassipes), Tricodherma sp. Mushrooms, 70\% alcohol, aquades and materials for making mini green houses. The tools used in this study were polybags $50 \mathrm{~cm}$ x $50 \mathrm{~cm}$, volume $500 \mathrm{ml}$ liter, label paper, measuring instruments, buckets, basins, writing instruments, cameras, mini green house making tools and other tools.

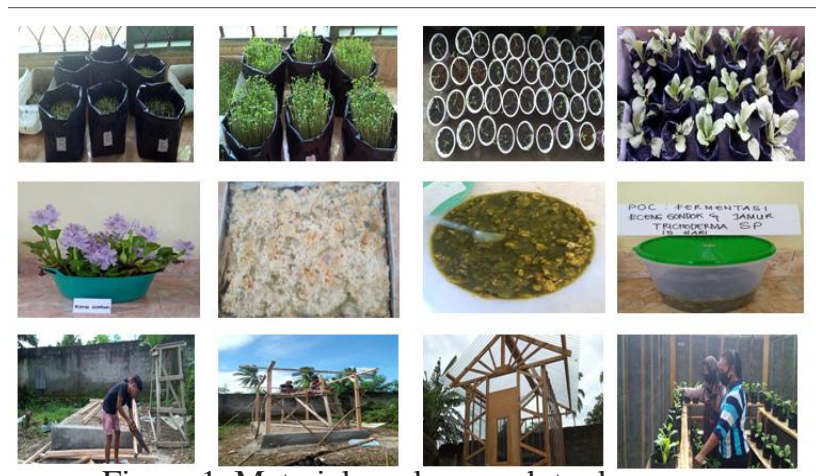

Figure 1. Materials and research tools

\section{Research design}

This study used a completely randomized design (CRD) with a single factor, namely water hyacinth liquid organic fertilizer (POC) fermented using the fungus Trichoderma $s p$. consisting of 5 levels of fertilization doses, namely A $(0 \mathrm{ml} / \mathrm{L}), \mathrm{B}(8$ $\mathrm{ml} / \mathrm{L}), \mathrm{C}(16 \mathrm{ml} / \mathrm{L}), \mathrm{D}(24 \mathrm{ml} / \mathrm{L})$ and $\mathrm{E}(32 \mathrm{ml} / \mathrm{L})$ with repeated 5 times.

\section{Making Trichoderma sp}

Made using materials and tools including: rice, bamboo compost, clean jars, clean cloths, paper and tissue, by being put in a clean jar lined with tissue and clean cloth and reproducing using bamboo compost medium.

\section{Making Water Hyacinth Liquid Organic} Fertilizer

Liquid organic water hyacinth fertilizer is made by mixing $5 \mathrm{~kg}$ of water hyacinth with 5 liters of coconut water, 5 liters of rice water and $1 / 4 \mathrm{~kg}$ of brown sugar, which is then put in a clean container (jar) and stored for 15 to 20 days. 


\section{Preparation of Planting Media}

The planting medium used was alluvial soil, which was obtained in the area of Central Maluku Regency, the soil was then sieved and put in a $10 \mathrm{~kg}$ polybag.

4. Seed Preparation

The green mustard plant seeds used are the mustard greens produced by PT. East West Seed Cap Red Arrow Shinta Brand. The green mustard plant seeds are sown by planting them in the seedling medium until the seeds grow and have four leaves.

\section{Planting}

The green mustard seeds which have four leaves are then transferred to the prepared planting medium and arranged according to the predetermined research design.

6. Provision of Water Hyacinth Liquid Organic Fertilizer

Water hyacinth liquid organic fertilizer is given when the plants are 7,14, and 21 DAP (day after planting) by watering / spraying them according to the treatment dose.

\section{Watering}

Watering is carried out every day by giving 500 $\mathrm{ml}$ of water per polybag.

\section{Plant Weed Management}

Plant weed management is carried out by cleaning / removing weeds that grow around the mustard greens.

\section{Results and Discussion}

Measurement of Height, Leaf Width and Number of Green Mustard Leaves Plant height

The measurement results of the height growth parameters of the mustard greens at the age of 4 weeks showed that the green mustard plant height varied from $19,7 \mathrm{~cm}$ to $27,7 \mathrm{~cm}$.

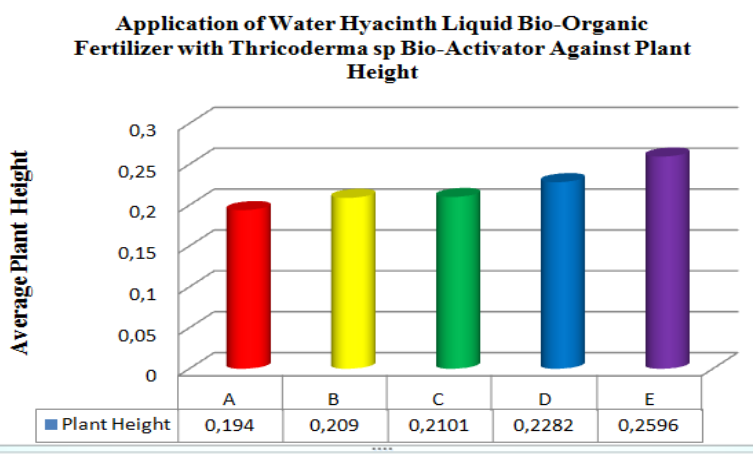

Figure 2. Average Height of Green Mustard Plants at 4 Weeks (21 day after planting)
In Figure 2, it can be seen that the highest average height of green mustard plants is $27.76 \mathrm{~cm}$ in treatment E, namely the dose of liquid bio-organic fertilizer for water hyacinth with bio-activator Thricoderma sp $32 \mathrm{ml} / \mathrm{L}$, while the shortest green mustard plant height is $19,7 \mathrm{~cm}$. Furthermore, the results of analysis of variance can be seen in Table 1 .

Table 1.Results of Analysis of Variety on Height of Green Mustard Plants at 4 weeks of age (21 day after planting)

\begin{tabular}{|l|l|l|l|l|l|}
\hline & Sum of Squares & df & Mean Square & F & Sig. \\
\hline Between Groups & 202,846 & 4 & 50,712 & 7,774 &, 001 \\
Within Groups & 130,472 & 20 & 6,524 & & \\
Total & 333,318 & 24 & & & \\
\hline
\end{tabular}

Based on the results of the analysis of variance in Table 1, it shows that the dose treatment of water hyacinth liquid bio-organic fertilizer with bioactivator Thricoderma sp has a significant effect, with a sig value of $0.001<7.774$ ( $\mathrm{p}<0.05)$, which means that there is a significant effect between treatments A, $\mathrm{B}, \mathrm{C}, \mathrm{D}$ and $\mathrm{E}$ on the height of mustard greens at the 4th week measurement (21 DAP).

\section{Leaf Width}

The results of measurement of leaf width growth parameters of 4 weeks old green mustard (21 day after planting) showed that the green mustard leaf width varied between $7,8 \mathrm{~cm}$ to $10,5 \mathrm{~cm}$.

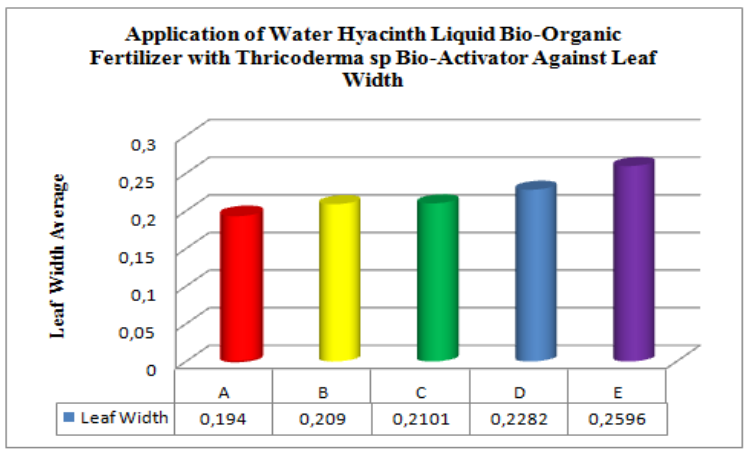

Figure 3. Average Width of Green Mustard Plant Leaf Width at 3 Weeks (14 day after planting)

In Figure 3, it can be seen that the highest average green mustard leaf width is $10,52 \mathrm{~cm}$ in treatment E, namely the dose of liquid bio-organic fertilizer for water hyacinth with bio-activator Thricoderma sp $32 \mathrm{ml} / \mathrm{L}$, while the shortest green mustard leaf width is $7.80 \mathrm{~cm}$. Furthermore, the results of analysis of variance can be seen in Table 2 . 
Table 2. Results of Sidik Analysis on Variety of Green Mustard Leaf Width at 4 Weeks (21 day after planting)

\begin{tabular}{|l|l|l|l|c|c|}
\hline & Sum of Squares & Df & Mean Square & F & Sig. \\
\hline Between Groups & 27,622 & 4 & 6,906 & 24,966 &, 000 \\
Within Groups & 5,532 & 20 &, 277 & & \\
Total & 33,154 & 24 & & & \\
\hline
\end{tabular}

Based on the results of the analysis of variance in Table 2, it shows that the dose treatment of water hyacinth liquid bio-organic fertilizer with bioactivator Thricoderma sp has a significant effect, with a sig value of $0,000<24,966$ ( $p<0.05$ ), which means that there is a significant effect between treatments A, $\mathrm{B}, \mathrm{C}, \mathrm{D}$ and $\mathrm{E}$ on leaf width of mustard greens at the 4 week measurement (21 Day after planting).

\section{Number of Leaves}

The results of the measurement of the growth parameters for the number of green mustard leaves aged 4 weeks (21 Day after planting) showed that the mustard greens had an average number of leaves that varied from 9 to 10,8 leaves.

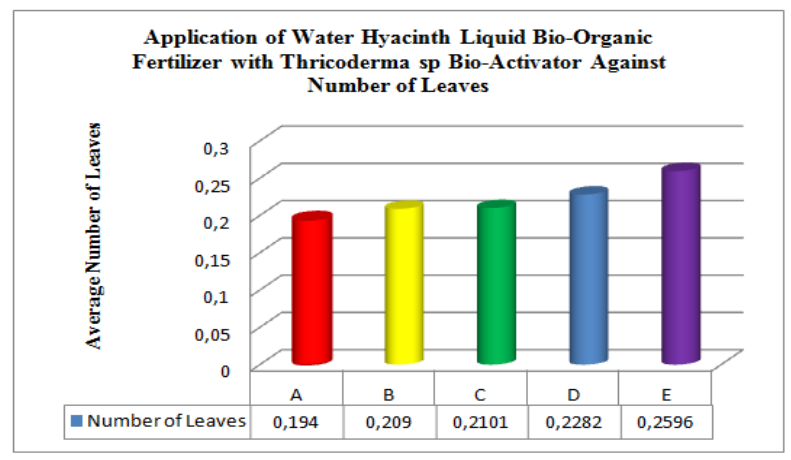

Figure 4. Average Number of Green Mustard Plant Leaves at 4 Weeks (21 day after planting)

In Figure 4, it can be seen that the highest average number of green mustard leaves is 10.8 leaves in treatment $\mathrm{C}$, namely the dose of water hyacinth liquid bio-organic fertilizer with bio-activator Thricoderma sp $16 \mathrm{ml} / \mathrm{L}$ and treatment E, namely the dose of liquid bio-organic fertilizer. Water hyacinth with Thricoderma sp. $32 \mathrm{ml} / \mathrm{L}$ bio-activator, while the lowest number of green mustard leaves was 9 strands found in treatment A, namely the treatment without a dose of water hyacinth bio-organic fertilizer with Thricoderma $s p$ bio-activator only with water.
Furthermore, the results of analysis of variance can be seen in Table 3.

Table 3. Results of Sidik Analysis of Variety of Leaf Number of Green Mustard Plants at 4 Weeks (21 day after planting)

\begin{tabular}{|l|l|l|l|l|l|}
\hline & Sum of Squares & df & Mean Square & F & Sig. \\
\hline Between Groups & 12,160 & 4 & 3,040 & 1,652 &, 200 \\
Within Groups & 36,800 & 20 & 1,840 & & \\
Total & 48,960 & 24 & & & \\
\hline
\end{tabular}

Based on the results of the analysis of variance in Table 3, it shows that the dosage treatment of water hyacinth liquid bio-organic fertilizer with bioactivator Thricoderma sp has a significant effect, with a sig value. equal to $0,200<1,652(\mathrm{p}<0,05)$, which means that there is a significant effect between treatments A, B, C, D and E on the number of green mustard leaves measured at week 4 (21 day after planting).

\section{Green Mustard Plant Height}

The results of the average plant height at week 4 showed that the best plant height increase was seen in treatment $\mathrm{E}$ with the addition of a dose of water hyacinth liquid bio-organic fertilizer with bioactivator Thricoderma sp $32 \mathrm{ml} / \mathrm{L}$, namely $27,76 \mathrm{~cm}$ while the shortest green mustard plant height was found in Treatment A was the treatment without a dose of water hyacinth bio-organic fertilizer with the bio-activator Thricoderma sp with only $19,7 \mathrm{~cm}$ of water. The results of this study indicate that the more application of liquid bio-organic fertilizer water hyacinth with the bio-activator Thricoderma sp can increase the height growth of green mustard plants. The increase in green mustard plant height was caused by the presence of N, P and $\mathrm{K}$ nutrient content in water hyacinth liquid bio-organic fertilizer, so the more organic fertilizers were given, the increased plant growth. It is in line with what was stated by (Rizqiani et al, 2007) that the higher the fertilizer dose given, the higher the nutrient content received by plants.

The growth of green mustard plant height is also influenced by the element $\mathrm{N}$, if the $\mathrm{N}$ element received by the mustard plant through a dose of liquid bio-organic fertilizer with a lot of Thricoderma sp bioactivator, the growth of mustard greens is higher, this is because the organic material contained in Water hyacinth has been broken down by bio-activator Trichoderma sp so that the organic elements in liquid organic fertilizers can provide $\mathrm{N}$ for green mustard plants (Hadisuwito, 2012). Whereas treatment A, namely the treatment without a dose of water hyacinth 
bio-organic fertilizer with bio-activator Thricoderma $s p$ only by giving water which was observed based on the average plant height at week 4 experienced obstacles in the growth process, this was because this treatment was not applied. Liquid bio-organic fertilizer for water hyacinth with bio-activator Thricoderma sp so that it lacks N, P and K elements, this is in line with what was stated by (Yulianti, et al, 2018) that if the plant lacks $\mathrm{N}$ it causes obstacles to plant growth so that it can cause stunted plants. The role of elemental $\mathrm{K}$ is also important as an activator of various enzymes and also influences nutrient absorption and photosynthate translocation so that without the $\mathrm{K}$ element, green mustard plants cannot achieve maximum growth (Lingga and Marsono, 2013).

\section{Leaf Width}

The results showed that the treatment with the application of liquid bio-organic fertilizer with water hyacinth bio-activator Thricoderma $s p$ on the width of the green mustard leaves showed that the dosage treatment had a significant effect on treatments A, B, C, D and E, this shows that the application of bio fertilizers. Liquid organic water hyacinth with bioactivator Thricoderma $\mathrm{sp}$ in the treatment can increase the availability of nutrients in the soil, while treatment $\mathrm{A}$ in the analysis of variance has a significant effect, but on the average leaf width week 4 the width of the leaves is the shortest. The results of the average plant height at week 4 showed that the best increase in leaf width was seen in treatment $E$ with the addition of a dose of water hyacinth liquid bio-organic fertilizer with bio-activator Thricoderma sp $32 \mathrm{ml} / \mathrm{L}$ which was $10,52 \mathrm{~cm}$ while the smallest green mustard leaf width contained in treatment $\mathrm{A}$, namely the treatment without a dose of water hyacinth bio-organic fertilizer with bio-activator Thricoderma $s p$, only with the provision of water, namely $7,8 \mathrm{~cm}$.

\section{Number of Leaves (Strand)}

The results showed that the results of the analysis of the variety of treatments A, B, C, D and E had a significant effect and the best average plant height occurred in treatments $\mathrm{C}$ and $\mathrm{E}$, namely the treatment with the application of liquid bio-organic fertilizer with water hyacinth bio-activator Thricoderma sp. with an average of 10,8 leaves and the lowest was in treatment A, namely 9 leaves.

The results of the study were clear that the higher the fertilizer treatment was given, the greater the number of green mustard leaves. (Zuhri and Armaini, 2009) stated that adding the element $\mathrm{N}$ as needed can increase the number of plant leaves. This shows that the higher the dose given, the higher the nutrient content received by plants. (Taufika, 2011) states that $\mathrm{N}$ contains protein and is useful for leaf shoot growth so that if the $\mathrm{N}$ content in POC is high it can stimulate shoot growth so that the number of leaves increases.

\section{Chemical Content Testing}

\section{Vitamin C levels}

In Figure 5, it can be seen that the vitamin $\mathrm{C}$ content of green mustard plants varies from $0.2975 \mathrm{mg} / 100 \mathrm{~g}$ of material to $0.22784 \mathrm{mg} / 100 \mathrm{~g}$ of material. The highest level of vitamin $\mathrm{C}$ was in treatment $\mathrm{E}$, namely the dose of liquid bio-organic fertilizer water hyacinth with bio-activator Thricoderma sp $32 \mathrm{ml} / \mathrm{L}$, while the lowest vitamin C level in treatment $\mathrm{A}$ was the treatment without dosage dose of water hyacinth liquid bio-organic fertilizer with bio-activator. Thricoderma sp only by giving water.

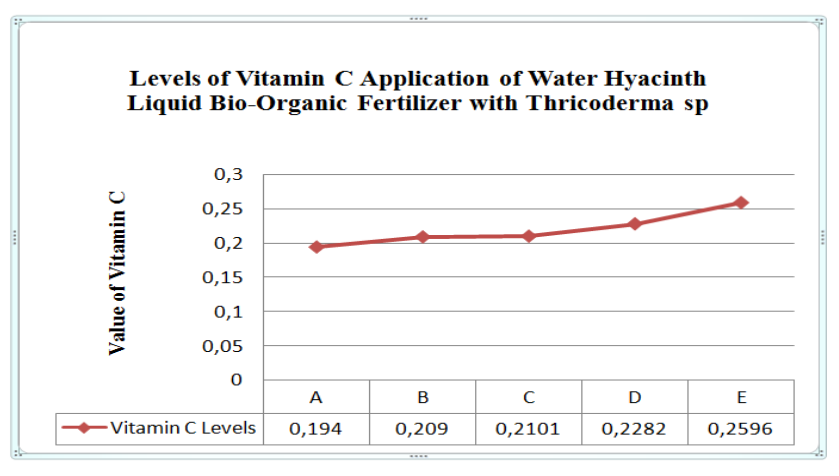

Figure 5. Vitamin C Levels of Green Mustard Plants

\section{Vitamin A levels}

In Figure 6 it can be seen that the vitamin A content of green mustard plants varies from 0,194 to 0,2596. The highest level of vitamin A was in treatment E, namely the dose of water hyacinth liquid bio-organic fertilizer with Thricoderma sp $32 \mathrm{ml} / \mathrm{L}$ bio-activator, while the lowest vitamin content was in treatment E, namely the dose treatment with the addition of water

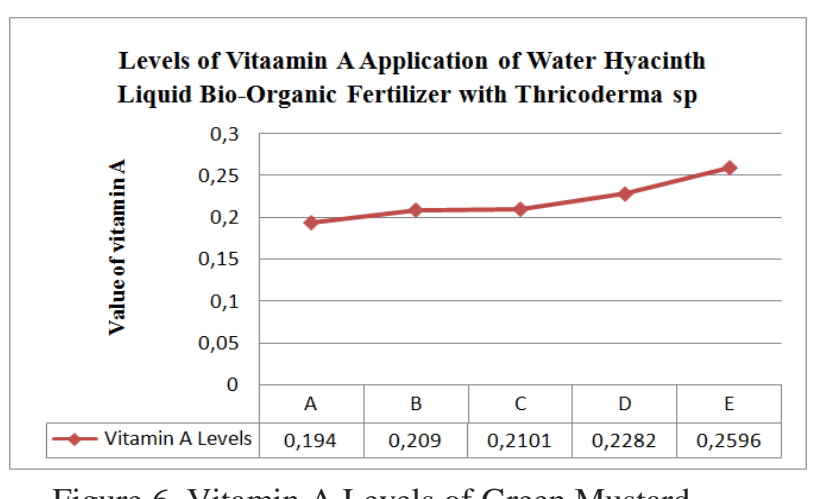

Figure 6. Vitamin A Levels of Green Mustard Plants 
(Johnson, et al 1991) and (Sandman, 1994) in (Madha, et al. 2010) suggest that one of the important factors in the biosynthesis of caretenoid (vitamin A), and vitamin C. According to (Bramley, 2002), the role of light is to increase the activity of enzymes that play a role in the biosynthesis process of rubberenoid (vitamin A), and vitamin C. Treatment E (dosage of water hyacinth liquid bio-organic fertilizer with Thricoderma sp $32 \mathrm{ml} / \mathrm{L}$ bio-activator) had a higher content of caretenoid (vitamin A) and vitamin C than other treatments because it was able to optimize light in the biosynthesis of Karetenoid (Vitamin A) and vitamin C. In addition, the role of water hyacinth which contains organic nutrients $\mathrm{N}, \mathrm{P}$ and $\mathrm{K}$ as raw material for making liquid organic fertilizer has an effect on the increase in gumenoids (vitamin A) and vitamin $C$ of green mustard plants at 4 weeks of plant age (21 day after planting).

Light energy absorption is also influenced by leaf morphology, treatment $\mathrm{E}$ (dose of water hyacinth liquid bio-organic fertilizer with Thricoderma sp 32 $\mathrm{ml} / \mathrm{L}$ bio-activator) at the age of 4 weeks (21 DAP) has the highest average leaf width of $10,52 \mathrm{~cm}$ so that light energy will be absorbed more optimally and cause caretenoid (vitamin A) and vitamin $\mathrm{C}$ to increase. In contrast to treatment A (without a dose of water hyacinth bio-organic fertilizer with bioactivator Thricoderma sp) which has the lowest average leaf width of $7,8 \mathrm{~cm}$ so that the absorption of light energy is small which results in caretenoid (vitamin A) and vitamin C. treatment A was lower. (Marjenah, 2001) in (Irwanto, 2009) states that due to limited light, plants will stimulate the formation of chlorophyll to efficiently capture light so that the content of caretenoid (vitamin A) and vitamin C of green mustard plants is 4 weeks old (21 day after planting) became abundant.

\section{Conclusions}

The results showed that the best dose was treatment $\mathrm{E}$ (dose of liquid bio-organic fertilizer water hyacinth with bio-activator Thricoderma sp $32 \mathrm{ml} / \mathrm{L}$ ) with a higher average plant height, leaf width and number of leaves compared to other treatments and containing vitamin A and high levels of Vitamin C, which contains rubberenoid vitamin A $(0,2596$ $\mathrm{mg} / 100 \mathrm{~g}$ material $)$ and vitamin $\mathrm{C}(0,2784 \mathrm{mg} / 100 \mathrm{~g}$ material). The results of this study are expected to be an alternative in the cultivation of horticultural crops by utilizing liquid bio-organic fertilizer with water hyacinth bio-activator Thricoderma $s p$ to increase plant growth and production.

\section{Acknowledgements}

Thanks to the Ministry of Research, Technology and Higher Education for funding assistance in this research through the research of beginners and to STKIP Gotong Royong Masohi who have provided the location for the construction of mini green houses and all parties who have helped in this research process.

\section{References}

Apzani W., Agung H., Wardhan W., Baharudin \& Arifin Z. (2017). Efektivitas Pupuk Organik Cair Eceng Gondok (Eichhornia crassipes) Fermentasi Trichoderma spp. Terhadap Pertumbuhan Selada (Lactuca sativa L.). Jurnal Sangkareang Mataram. ISSN No. 23559292. $3 \quad$ (3), September 2017. http://www.untb.ac.id/september-2017/

Bramley. P M. (2002). Regulation of carotenoid formation during tomato fruit ripening and development. Journal of Experimental Botany, 53 (377), Fruit Development and Ripening Special Issue, pp. 2107 2113, October 2002. DOI: $10.1093 / \mathrm{jxb} / \mathrm{erf026}$

Erawan D., Yani WO. \& Bahrun A. (2013). Pertumbuhan dan Hasil Tanaman Sawi (Brassica juncea L.) Pada Berbagai Dosis Pupuk Urea. Jurnal Agroteknos Maret 2013, 3 (1), 19-25 ISSN: 2087-7706. https://adoc.pub/pertumbuhan-dan-hasiltanaman-sawi-brassica-juncea-l-pada-be.html

Gardner, F.P., R.B Pearce \& R.L. Mitcel (2008). Fisiologi Tanaman Budidaya. Penerbit Universitas Indonesia. Jakarta.

Hadisuwito, S. (2012). Membuat Pupuk Organik Cair. PT. Agro Media Pustaka: Jakarta Selatan

Istraofah \& Salamah Z. (2017). Pertumbuhan Tanaman Sawi Hijau (Brassica Juncea L.) dengan Pemberian Kompos Berbahan Dasar Daun Paitan (Thitonia diversifolia). Bio-site. 03 (1): 39 - 46 ISSN: 2502-6178. https://onlinejournal.unja.ac.id/index.php/BST/index

Juliani R., Simbolon RFR, Sitanggang WH. \& Aritonang JB., (2017). Pupuk Organik Enceng Gondok dari Danau Tob. Jurnal Pengabdian Kepada Masyarakat. 23 (1), Januari - Maret 2017 p-ISSN: 0852-2715 | e- 
Febiayu \& Centhya (2020). Jurnal Biologi Tropis, 20 (3): 388 - 395 DOI: http://dx.doi.org/10.29303/jbt.v20i3.2058

ISSN: 2502-7220.

https://jurnal.unimed.ac.id/2012/index.php/j $\mathrm{pkm/article/view/6637}$

Kaya, E., Silahooy, Ch. \& Risambessy, Y., (2017). Pengaruh Pemberian Pupuk Organik Cair dan Mikroorganisme Terhadap Keasaman dan PTersedia Pada Tanah Ultisol. Jurnal Mikologi Indonesia, 1 (2): 91-99 ISSN: 2579-8766. https://core.ac.uk/download/pdf/267851529. pdf

Lehar, L. (2012). Pengujian Pupuk Organik Agen Hayati (Trichoderma sp) terhadap Pertumbuhan Kentang (Solanum tuberosum L). Jurnal Penelitian Pertanian Terapan, 12 (2): $\quad$ 115-124 ISSN1410-5020. https://media.neliti.com/media/publications/ 139572-ID-pengujian-pupuk-organik-agenhayati-tric.pdf

Lingga, P \& Marsono (2013). Petunjuk Penggunaan Pupuk Edisi Revisi. Penebar Swadaya. Jakarta

Lestari DS, Brata KR. \& Widyatuti R. (2017). Pengaruh Trichoderma Sp. Dan Molase Terhadap Sifat Biologi Tanah Di Sekitar Lubang Resapan Biopori Pada Latosol Darmaga. Buletin Tanah dan Lahan, 1 (1) Januari 2017: 17-22. https://journal.ipb.ac.id/index.php/btanah/art icle/download/17686/12660/

Mahanta, K., Jha, DK., Rajkhowa DJ, \& Manoj (2012). Microbial enrichment of vermicompost prepared from different plant biomasses and their effect on rice (Oryza sativa L.) growth and soil fertility Biological Agriculture and Horticulture. 2012; 28(4): 241-

250.

https://doi.org/10.1080/01448765.2012.7385 $\underline{56}$

Marianah, L. (2013). Analisa Pemberian Trichoderma sp. Terhadap Pertumbuhan Kedelai. Karya Tulis Ilmiah. Balai Pelatihan Pertanian Jambi

Madha K., M. Izzati, M. \& Nurchayati, Y. (2010). Kandungan Klorofil, Karotenoid, dan Vitamin C pada beberapa Spesies Tumbuhan Akuatik. BULETIN ANATOMI DAN FISIOLOGI dh SELLULA, 18 (1), Mar.2012. https://doi.org/10.14710/baf.v18i 1.2614
Osoro, N., Jhon, O., Muoma, Amoding, A., Mukaminega, D., Muthini, M., Ombori, O., \& Maingi, J.M. (2014). Effects of Water Hyacinth (Eichhornia Crassipes [Mart.] Solms) Compost On Growth And Yield Parameters Of Maize (Zea Mays). British Journal of Applied Science \& Technology 4(4): $\quad$ 617-633,2014. https://www.researchgate.net/publication/29 2717855_Effects_of_Water_Hyacinth_Eich hornia_crassipes_mart_solms_Compost_on_ Growth and Yield Parameters of Maize $\underline{\text { Zea_mays }}$

Ratnani, Rita, Hartati \& laeli Kurniasari (2011). Pemanfaatan Eceng Gondok (Eichornia crassipes) Untuk Menurunkan Kandungan COD (Chemical Oxygen Demond), pH, Bau dan Warna pada Limbah Cair Tahu. Jurnal Momentum, $\quad 7(1)$ : 41-47. https://media.neliti.com/media/publications/ 113323-ID-none.pdf

Rizqani, N. F. Erlina, A. \& Nasih, W, Y. (2007). Pengaruh Dosis dan Frekuensi Pemberian Pupuk Organik Cair Terhadap Pertumbuhan dan Hasil Buncis (Phaseolus vulgaris L) Dataran Rendah. Jurnal Ilmu Tanah dan lingkungan. 7 (1): 43-53. http://blog.ub.ac.id/puspitt/files/2012/12/pup uk-cair.pdf

Rorong JA \& Suryanto E. (2010). Analisis Fitokimia Eceng Gondok (Eichhornia crassipes) dan Efeknya sebagai Agen Photoreduksi Fe3+. 41. $\square$ Chemistry Progress. 3(1):33. https://ejournal.unsrat.ac.id/index.php/chem prog/article/view/72

Stefhani CA, Mumu S. \& Pharmawati K. (2013). Fitoremediasi Phospat dengan Menggunakan Tumbuhan Eceng Gondok (Eichhornia crassipes) pada Limbah Cair Industri Kecil Pencucian Pakaian (Laundry). Reka Lingkungan Jurnal Institut Teknologi Nasional.11. $\square$ 1(1):1. https://ejurnal.itenas.ac.id/index.php/lingkun gan/article/viewFile/137/2315

Taufika R. (2011). Pengujian Beberapa Dosis Pupuk Organik Cair terhadap pertumbuhan dan Hasil Tanaman Wortel (Daucuscarota L). Jurnal Tanaman Holtikultura. http://repository.unand.ac.id/17098/1/JURN AL_RAHMI_TAUFIKA_\%2807111017\%2 9.pdf 
Febiayu \& Centhya (2020). Jurnal Biologi Tropis, 20 (3): 388 - 395

DOI: http://dx.doi.org/10.29303/ibt.v20i3.2058

Yuliatin, E., Sari, Y.P. \& Hendra, M. (2018). Efektivitas Pupuk Organik Cair dari Eceng Gondok (Eichornia crassipes (Mart), Solm) untuk Pertumbuhan dan Kecerahan Warna Merah Daun Aglaonema „Lipstik .Jurnal Biotropika, 6 2018.DOI: 10.21776/ub.biotropika.2018.006 .01 .6
Wulandari, D., Linda, R \& Turnip, M. (2016). Kualitas Kompos Dari Kombinasi Eceng Gondok (Eichornia crassipes Mart. Solm) Dan Pupuk Kandang Sapi Dengan Inokulan Trichoderma harzianum L. Protobiont $\begin{array}{llll}\text { (2016), } & 5 & \text { (2): } & 34\end{array}$ https://jurnal.untan.ac.id/index.php/jprb/artic $\underline{\text { le/view/15930 }}$ 